\title{
Deconstructing the Origins of Cressey's Fraud Triangle
}

Abstract

Peter Tickner and Mark Button

Journal of Financial Crime, June 2021.

Purpose

Cressey's Fraud Triangle has been referenced in 8,584 articles and academic papers ${ }^{[1]}$ and is a stalwart of training courses for accounting and audit practitioners and fraud investigators. The Fraud Triangle has endured for three decades in the academic and practitioner worlds. This article explores the origins of Cressey's Fraud Triangle and challenges its practical value to a fraud investigator.

\section{Design/methodology/approach}

This article has developed from analysis of a targeted literature review carried out as part of a wider study into occupational fraud and corruption.

\section{Findings}

Cressey's name is intrinsically linked to the Fraud Triangle, although he never used the expression during his lifetime. Two of the three motivational factors identified by Cressey (1953) were developed from the earlier work of Svend Riemer (1941), who it is suggested should have equal billing with Donald Cressey for the concepts that led to the creation of the Fraud Triangle.

\section{Originality}

Many academics and researchers have either misunderstood Cressey's role in the development of the Fraud Triangle or been unaware of its true origins. Although the pioneering work of Riemer is referenced in a 2013 article on the Fraud Triangle by Alexander Schuchter and Michael Levi, this paper is the first to identify the influence of Riemer on Cressey's thinking and the development of the Fraud Triangle.

\section{Keywords}

Fraud Triangle, Fraud, Embezzlement, Cressey, Occupational Fraud, White Collar Crime, Sutherland, Criminology

\section{Introduction}

The Fraud Triangle concept links three conditions that need to be present for an individual to be motivated to commit a fraud - a perceived pressure, a perceived opportunity to commit the fraud and the ability to rationalise the fraudulent behaviour to make it acceptable. This model, promulgated by the ACFE and others, is a logical interpretation of Cressey's research and of 
relevance to social science and the discipline of criminology but in the authors' view has limited relevance to practitioners.

Several authors have also tried to build on the foundations of the fraud triangle. The fraud diamond of Wolfe and Hermanson (2004), the fraud M.I.C.E. (Money, Ideology, Coercion and Ego) Kranacher et al (2010), the Fraud Square of Cieslewicz 2010, 2012) adding a fourth side to the Fraud Triangle to represent societal influences, the Fraud Balance theory of Albrecht et al, $(1979,1981)$ and Schuchter and Levi's replacement of rationalisation with the concept of the 'inner voice' (2015), to name some.

\section{Background}

It is unusual to attend a fraud investigator training course and not to at some point come across Cressey's Fraud Triangle. In its simplest form the triangle can be described in three words, 'pressure', 'opportunity' and 'rationalisation'. These are derived from Cressey's PhD thesis in the late 1940s in which he tested the hypothesis that 'Trusted persons become trust violators when they perceive of themselves as having a financial problem which is non-shareable [pressure], are aware that this problem can be secretly resolved by violation of the position of financial trust [opportunity], and are able to apply to their own conduct in that situation verbalizations which enable them to adjust their conceptions of themselves as trusted persons with their conceptions of themselves as users of the trusted funds or property [rationalisation]' (Cressey, 1953, p30).

Cressey's criminological research in the 1940s was conducted into an exclusively male population of 133 convicted embezzlers out of an initial sift of 503 convicts in three US prisons who potentially could be included in the population of convicted embezzlers. Some of the embezzlers researched were not fraudsters but opportunistic thieves. Cressey also chose to exclude convicted embezzlers who were serial or habitual criminals and had not therefore accepted a position of trust in good faith (Cressey, 1953, p23). While the research conclusions may be relevant to understanding the motives of otherwise non-criminal male fraudsters in the US in the 1940s, by the nature of the study it is a research population limited in its interpretation by era, geography, sex, being imprisoned and nonhabitual.

It is perhaps surprising to discover that although Cressey developed the hypothesis for his PhD thesis from his research into convicted embezzlers and described its genesis in a book published in $1953^{[2]}$, Cressey never himself referred to a fraud or embezzlement triangle in any of his published work. So perhaps the first important question is where did the fraud triangle come from?

\section{A little history}

Donald Ray Cressey was a sociologist and criminologist. He studied under the eminent criminologist Edwin Sutherland, who was the first person to coin the phrase 'white collar crime'. At the time when Cressey was studying and researching for his own PhD, Sutherland had already developed a general theory of why individuals become criminals. Sutherland theorised that criminal behaviour was learned from others rather than an inherent trait or characteristic of certain types of individuals. From this he had developed his theory of 'Differential Association' during the 1920s and 1930s, first 
publishing it in $1939^{[3]}$. Sutherland felt that the common perception at the time that only the lower classes and those who were abnormal or had an underlying psychological condition committed crimes was wrong and did not take into account the possibility of differential association and criminality as learned behaviour. Sutherland also felt strongly that society had developed mechanisms that allowed white collar criminals at the upper end of society running major corporations to avoid the consequences of their criminality in a way that the lower classes could not. He expounded the view that white collar criminals also learnt their behaviour from others of their type, either because it was common practice in their business or because of relationships with likeminded businessmen.

Around the same time that Sutherland was developing his theory of differential association, a German occupational psychologist and academic who had been publicly critical of Hitler's rise and anti-Semitic policies in Germany, Svend Riemer, found it necessary to move to Sweden when Hitler became Chancellor in 1933. While teaching at a Swedish university, Riemer researched the backgrounds of 100 Swedish embezzlers who had either pleaded insanity or had been considered insane and were being kept and assessed at a specialist prison. When the $2^{\text {nd }}$ World War broke out Riemer moved to the US where he published the results of his studies of Swedish embezzlers in the US Journal of Criminal Law and Criminology in 1941. Significantly, Riemer concluded that most embezzlers had suffered a crisis of some kind relatively late in their chosen careers when they had been entrusted with significant sums of money. In his view they were not individuals who had chosen a life of crime or they would not have reached a position of trust to enable the opportunity of embezzlement to arise. Riemer's analysis of Swedish embezzlers identified three common factors. In his own words:

'1) The social pull; the opportunity

2) The social push; the emergency situation

3)...the psycho-pathological element involved.'

1) The social pull; the opportunity

For Riemer, embezzlers were uniquely different from other convicted criminals in that they had honestly reached or obtained a position in an organisation where they were entrusted with funds. This gave them the opportunity to embezzle from the funds entrusted to them. They were also likely to possess the technical knowledge to hide any embezzlement from immediate discovery.

\section{2.) The social push; the emergency situation}

Riemer identified that out of his 100 cases fewer than 12 lacked immediate economic strain. He concluded that there were generally three scenarios for the emergency situation: 1 . extreme poverty; 2 . a declining career creating financial pressures; 3 . career instability and insecurity causing the individual to consider embezzlement.

\section{3.) the psycho-pathological element involved}

Riemer was keen to emphasise that he did not mean that embezzlers might be feeble-minded or suffering from ongoing mania or paranoia, an explanation for general criminal behaviour which 
psychologists and criminologists had espoused in earlier studies (e.g. Goddard (1914), Freud (1916), Doll (1920) and Zeleney (1933)). Rather he thought that for some embezzlers the emotional stress of the emergency situation had caused a disassociation from the social values they would normally follow, in some cases there was evidence of slightly paranoid behaviour in desperate attempts to resolve their situation and for others, character weaknesses, such as alcoholism, had been present before the embezzlement started. Where the embezzler had close dependents and family they were more likely to feel the psychological pressure to embezzle in order to maintain expected lifestyles.

It is no coincidence that there is a resonance between Riemer's three factors and the three elements of the fraud triangle as we know it today. Cressey, who first formulated the elements that make up the fraud triangle, was well aware of Riemer's paper at the time of his own research and referenced its influence on his thinking in his own published work that forms the basis for the fraud triangle.

Riemer had seen an article by Sutherland in 1940 on white collar crime and how it might link with differential association theory. Riemer $(1941, \mathrm{p} 412)$ noted in his own paper that in 45 of the 100 embezzlers he studied 'they did not require any more opportunities than those open to every citizen with average insight into the functioning of our most elementary economic institutions. If more extensive research should confirm these conditions, the theory of white collar crime originating in the professional atmosphere of civil service and business life might have to be somewhat revised.' [Riemer's footnote to this paragraph refers specifically to Sutherland's White Collar Criminality article in the American Sociological Review of February 1940.]

For his PhD under Sutherland's tutelage, Cressey determined to study embezzlers in the US and establish whether the theories of Riemer or Sutherland were most relevant as to the reasons why individuals were motivated to become embezzlers. Initially he was naturally influenced towards Sutherland's differential association theory but soon found that it did not seem to fit with all the embezzlers whose cases he was studying. Eventually he revised his hypothesis to bring in the factors that Riemer had identified in his earlier study of Swedish embezzlers. This led Cressey to the hypothesis we now know as Cressey's fraud triangle.

After Cressey published his hypothesis in the best-selling book 'Other People's Money', Cressey moved on to other aspects of criminology, particularly organised crime and the mafia, and did not conduct any further significant research of his own into white collar criminology. ${ }^{\left[{ }^{[5}\right.}$

Cressey's work might have stayed entirely in the realm of academe as a seminal work in criminology within the social sciences if it were not for Joseph Wells and Steve Albrecht. Wells founded the Association of Certified Fraud Examiners in 1988, with Albrecht as its first president. Prior to that Wells had been an $\mathrm{FBI}$ agent specialising in white collar crime and had then left to form his own investigative business. While researching a case for a corporate client in 1983, Wells became aware of Cressey's 'Other People's Money' and contacted Cressey, who was now a professor of criminology. They became firm friends for the last few years of Cressey's life (he died of a heart attack in 1987). Cressey's thinking on combining the role of an auditor or accountant with that of a fraud investigator led to Wells deciding to set up the ACFE in 1988 with that purpose in mind. Wells talked regularly about Cressey's hypothesis for the motivation of embezzlers on his training courses, but it was Albrecht, an academic accountant, who developed for ACFE the concept of the Cressey Fraud Triangle that we know today. 
Albrecht et al., 1982 had carried out a major study of the motivation of fraudsters with a KPMG grant. The research leaned heavily on the earlier work of Cressey and the key element of the published research in 1979 and a book based on it in 1982 was the development of a 'fraud balance' - a model to explain why fraudsters commit fraud that consisted of three inter-connected elements operating on a sliding scale:

1. Situational pressures

2. Opportunities to commit fraud

3. Personal integrity

While these remained in 'balance' or tilted towards the honest side of the scale, individuals would be unlikely to commit fraud, but once the weight of the balance was on the dishonest side then the likelihood of fraud being committed was increased.

Steve Albrecht continued to lecture and advise businesses on fraud, as well as becoming the first president of the ACFE at the request of Joseph Wells after its formation in 1988. Both gave lectures on fraud motivation that tapped directly into the three common factors that Cressey had found from his earlier research. Albrecht noted in an interview for the ACFE's Fraud magazine in $2014^{[5]}$ that at some point between 1988 and 1991 he'd been lecturing to a group of employees at a company when one of the employees noted that these three elements present for a fraud to occur were like the 'fire triangle' of fuel, heat and oxygen. All three elements were needed to cause a fire but it could be brought under control or stopped by the absence of any one of the three elements. Albrecht wrote about this in an article for the Government Finance Review in December 1991 when for the first time in print the expression 'Fraud Triangle' is seen in the context of Cressey's three factors that needed to be present for an act of embezzlement to take place.

Albrecht's 1991 article identified the three factors of the fraud triangle as:

1. Perceived Pressure

2. Perceived opportunity

3. A way to rationalize the behaviour as acceptable (see figure 1).

The use of the expression took off and the clear link back to Cressey's 1953 book and earlier PhD thesis soon led to it becoming called 'Cressey's Fraud Triangle'. In Cressey's original research of convicted embezzlers he had identified 'perceived pressure' as a 'non-shareable financial problem' for someone in a position of trust who had the opportunity to abuse that trust to solve their financial problem and could rationalise their behaviour so that in other ways they could continue to function as an 'honest citizen'. Albrecht went further and based on research conducted looking at the motives of fraudsters for the Institute of Internal Auditors (Albrecht et al, 1984) had amended the 'non-shareable financial problem' to be more broadly a perceived financial pressure whether or not it was perceived to be shareable.

Figure 1. 'Cressey's fraud triangle 


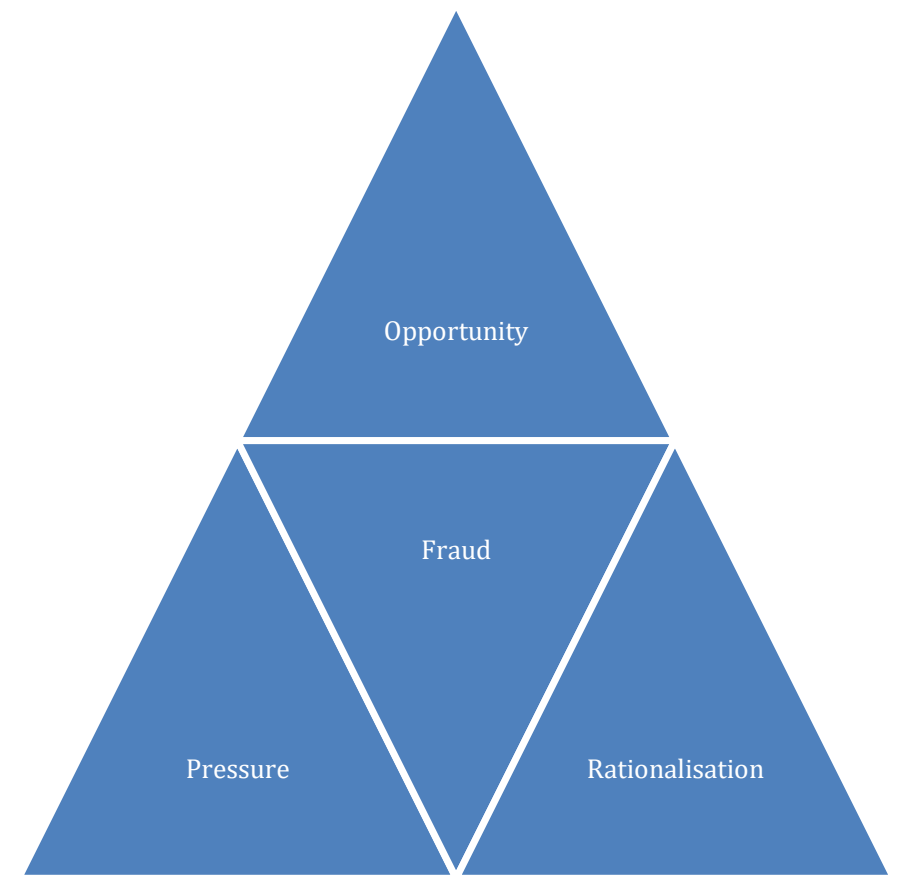

\section{Where next for the fraud triangle?}

The Fraud Triangle has proved to be a simple and enduring model for fraud motivation. More than eight thousand academic articles have been spawned on the back of it as well as numerous research projects and studies. ${ }^{[6]}$ There have been several attempts to enhance the Fraud Triangle with varying degrees of success. Perhaps the most successful to date has been the 'Fraud Diamond' proposed by Wolfe and Hermanson in 2004 and endorsed by Albrecht himself. The fourth element added to make up the diamond is 'capability' - a suggestion that even if the other three elements are present not all will have the capacity, confidence or intent to commit a fraud. 'Capability' is a good match with the psycho-pathological element identified by Riemer as the third factor in his 1930s study of imprisoned Swedish embezzlers.

Figure 2. Wolfe and Hermanson's fraud diamond 


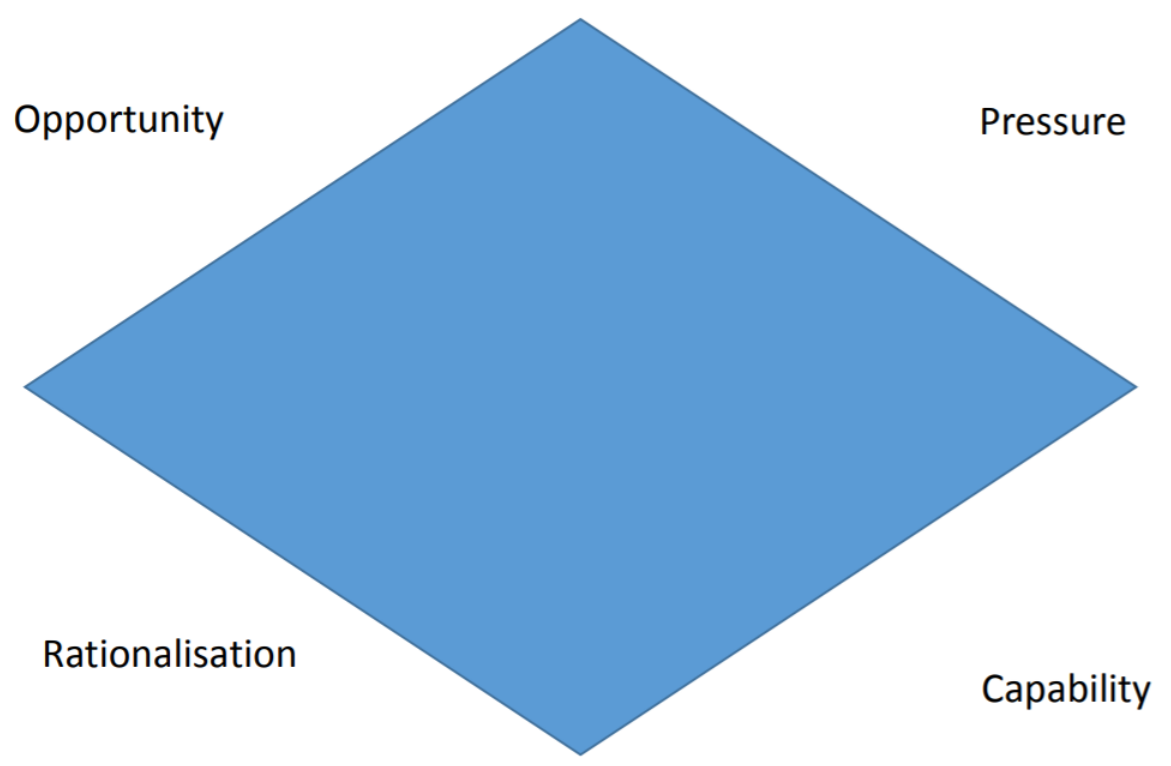

Another suggested enhancement that has had some success and support from Wells and others at the ACFE is the M.I.C.E. ${ }^{[7]}$ acronym for identifying the motives of a fraudster.

M.I.C.E. = Money, Ideology, Coercion and Ego

It is a useful acronym for the motivation of the type of fraudster that Sutherland had in mind when writing about white collar crime, senior or chief executives of corporations who are under no obvious personal financial pressure but choose to commit fraud. Cressey had always recognised that while his three factors explained all the cases that he had researched, as well as all that had been earlier researched by Sutherland for his white collar crime writings, it was possible future cases would not map onto his hypothesis and that it would need further revision.

The problem with the MICE acronym is that it almost excludes the motives of many that would meet Cressey's fraud triangle. Middle and lower management fraudsters are less likely to be motivated by ego and ideology.

Cieslewicz proposed a Fraud Square in 2010 and again in 2012, suggesting adding a fourth side to the Fraud Triangle to represent societal influences. To date this idea has not gathered any support outside of a limited academic circle.

In Europe, Schuter and Levi conducted a study of 13 Swiss top management embezzlers in 2014 (published January 2015) and discovered that, although opportunity was a factor in all cases, pressure was not perceived as one by the individuals in the study, although Schuter and Levi concluded that in some cases it was present. More significantly, rationalisation had not occurred in these cases of top management white collar fraud, but rather the individuals had an inner voice of conscience before the act which had to be quietened for the fraud to occur and then a guilty conscience after the fraud act was committed. 
In addition to those academics who have attempted to enhance the Fraud Triangle to address perceived weaknesses in the model, it has been subject to more direct criticisms by some. Close examination of the development of the Fraud Triangle has led to criticism of the interpretation placed on the work of Cressey by Wells and Albrecht, suggesting that interpretations favourable to the activities of the ACFE were promulgated without any scientific basis (Morales et al (2014)). Others such as Huber (2017) have been critical of the model itself and perceived gaps in Cressey's original research.

\section{The relevance of the Fraud Triangle in the prevention and detection of fraud}

For the prevention of internal fraud, organisations may be able to take steps to minimise the risk that an employee perceives an opportunity to violate trust and to mitigate perceived financial pressures (eg debt counselling, financial checks before moving an employee into a position of financial trust) but the fraud triangle will not enable an organisation to evaluate the risk that an employee may or may not be psychologically inclined to resolve a perceived pressure by committing fraud. It is perhaps one of the biggest criticisms of the theory from a social sciences perspective in that it does not explain why in apparently identical pressure and opportunity situations some employees commit fraud and others don't.

Another fundamental weakness in most of the academic studies related to the fraud triangle is that by their nature they are based around research into convicted criminals. By definition a convicted fraudster is an unsuccessful one and their case is being considered after the event. There is no known research into the motivations and rationalisations of successful or currently active fraudsters or indeed any significant research into whether the same individual might commit fraud in one particular set of circumstances but not in others.

Of the three elements of the fraud triangle, from an organisational point of view, the only one that can be generally known about is that of opportunity. Most organisations of any significant size will have systems in place to identify risks, including the opportunity of an individual or groups of individuals to commit fraud against the organisation. Most organisations will also have systems of internal control designed to reduce the risk of fraud as well as arrangements for audit and inspections that should mitigate the risk of fraud as well as prevention measures such as awareness training and whistleblowing arrangements. An effective organisation can therefore have efficient and effective prevention measures in place, but there is no system solution that can guarantee to prevent all fraud for any organisation that has any financial interaction either internally or with other organisations or individuals.

Once any fraudster or embezzler has been caught and is facing a criminal sanction then as part of their defence they will start to rationalise their behaviour, even if they had not rationalised it before they were caught. There are no studies however that can demonstrate how to detect how well an individual might be able to rationalise their behaviour in order to commit a fraud while remaining otherwise loyal or working effectively for an organisation.

While counselling, welfare and debt management services are often offered by larger organisations to their employees, generally such activities are treated as a confidential dialogue between the 
employee and the support services of the organisation. It is therefore unlikely that line or business function management would have awareness of circumstances that might make an employee perceive a financial pressure that causes them to defraud their employer.

It can be seen from the above that there is little of any practical value in Cressey's Fraud Triangle for an organisation or those charged by an organisation with the responsibility for preventing or detecting fraud against the organisation.

Once a fraud by an individual has been detected it is possible that the Fraud Triangle can be of relevance, particularly to any criminal investigation. This is less so for either civil actions to recover or prevent fraud or where the fraud is not committed by an internal employee or contractor to the organisation.

For criminologists and social scientists with an interest in researching or studying fraud or embezzlement the Fraud Triangle is a useful jumping off point for further research and study. The basis of the Fraud Triangle model is research conducted by three academics (Riemer, Sutherland and Cressey) in the 1930s and 1940s into an exclusively white male population of middle class embezzlers (as defined in either Swedish or US law respectively) who had been convicted and were in prison at the time of the research. While providing useful insights these studies are frozen in time and do not offer any insights into the more diverse workforce (both in terms of sex and ethnicity) that is found in most organisations today. Dorothy Zeitz's $1981^{[8]}$ study of women who embezzle and defraud evaluated the similarities and differences between male and female embezzlers in the context of Cressey's conclusions in 'Other People's Money' (Cressey provided Zeitz with advice and access to his earlier research papers). Zeitz's study identified four types of behaviour in women who had not set out to be dishonest but had violated a position of financial trust: (1) the obsessive protectors, (2) romantic dreamers, (3) greedy opportunists, and (4) victims of pressure or persuasion. Only the last two types could be said to sit clearly within Cressey's original hypothesis for male embezzlers. Zeitz found both similarities and differences to Cressey in rationalisations by convicted female embezzlers.

\section{Conclusion}

The Fraud Triangle is a useful tool for explaining the circumstances in which an individual could be motivated to commit fraud against an organisation where they hold a position of trust. It is however an extension and distortion of the original intentions of Cressey's work, itself conducted in an era where the workforce and the methods of working were far removed from those we see today. It is important to understand the shortcomings of the Fraud Triangle and the limitations that ought to be placed on its relevance to the prevention and detection of fraud as well as its specific relevance to certain aspects of criminology before its research value can be seen in context.

The Fraud Triangle was identified by Albrecht in 1991 as a development from the work of Cressey forty years earlier. Cressey in turn owed much to the previous research analysis by Riemer, taking two of the three key elements of his hypothesis and later the basis of what we now know as the fraud triangle directly from Riemer. There is a convincing argument that 'Cressey's Fraud Triangle' 
should be re-badged as the 'Riemer-Cressey Fraud Triangle' or, more accurately, the Riemer-Cressey Embezzlement Triangle.

\section{Notes}

[1] Source EBSCO publishing database, University of Portsmouth library resources September 2020

[2] Other People's Money: A study in the social psychology of embezzlement

[3] As explained by Sutherland himself in an article' The Development of the Theory of Differential Association', The Ohio Valley Sociologist, Vol 15 No1 (May 1942) p3. It first appeared in print as a theory as a late additional revision to the 1939 revision of Sutherland's Principles of Criminology, as later noted by Cressey.

[4] After Sutherland's sudden death following a stroke in 1950, Cressey also took over the editorship of 'Principles of Criminology', the criminology textbook first produced by Sutherland in 1924 and revised at intervals after that date.

[5] Albrecht made this claim in an article published by the ACFE's Fraud magazine in 2014. Ironically, in 2011 Morales, Gendron and Guenin-Paracini (2014) had contacted the ACFE by email and received a response which included:

"Actually, Dr. Wells is the first person we know of to take the three items and put [them] in a triangle format. He was working on a video featuring Dr. Cressey in 1985, and he used a triangle graphic in the video to illustrate the 3 factors that are present in most white-collar offenses. He began using the triangle graphic in training programs after that time. People saw the graphic and began referring to it as the Fraud Triangle over the years. So although we have never undertaken an extensive review of its use, as far as we know, that's how it came about."

[6] The number of 'hits' obtained through EBSCO database access via University of Portsmouth library in September 2020 when selecting search terms limited to academic journals and full text articles that contain the term 'Fraud Triangle' in the text or title.

[7] The origins of the M.I.C.E. acronym are accredited to Professor Jason Thomas at West Virginia University by Kranacher, Riley and Wells $(2010,2011)$, although Thomas himself has not published a paper in any recognised journal about M.I.C.E. At the time Thomas was an associate professor attached to the fraud and forensic auditing training programme at West Virginia University, his specialist knowledge though was in the field of political sciences and cybercrime.

[8] Zietz, D. (1981). Women who embezzle or defraud: A study of convicted felons. New York, NY: Praeger. In the preface Zeitz acknowledges the support she received from Cressey while conducting her research.

\section{Bibliography}

Albrecht, W. S., Romney, M. B., Cherrington, D. J., Payne, I. R., Roe, A. V. (1982), How to Detect and Prevent Business Fraud, Prentice Hall, New Jersey

Albrecht, W.S., Romney, M. B., Howe, K. R. (1984) Deterring fraud: The internal auditor's perspective, Institute of Internal Auditors Research Foundation, Altamonte Springs, Florida 
Albrecht, W. S. (1991), "Fraud in Government Entities: The Perpetrators and the Types of Fraud", Government Finance Review, December 1991, pp27-30

Albrecht, W. S. (2014), “Iconic Fraud Triangle endures", Fraud magazine, July/August 2014, pp1-4 Cieslewicz, J.K. (2010) "The fraud square: Societal influences on the risk of fraud", Paper presented at 2010 American Accounting Association Annual Meeting, 31 July-4 August, San Francisco.

Cressey, D.R. (1953), Other People's Money: A study in the social psychology of Embezzlement, The Free Press, Glencoe, Illinois

Doll, E. A. (1920), "The comparative intelligence of prisoners", Journal of Criminal Law and Criminology, Vol XI, pp191-197

Dorminey, J., Fleming, A. S., Kranacher, M.-J., Riley, R. A. (2012). The Evolution of Fraud Theory. Issues in Accounting Education, no. 27 (2), pp. 555-579

Freud, S. (1916). "Some Character-Types Met with in Psycho-Analytic Work". The Standard Edition of the Complete Psychological Works of Sigmund Freud, Volume XIV (1914-1916), (Criminals From a Sense of Guilt, pp331-332)

Goddard, H. H. (1914), Feeblemindedness: its causes and consequence, Macmillan, New York

Huber, W. D. (2017) "Forensic Accounting, Fraud Theory, and the end of the Fraud Triangle", Journal of Theoretical Accounting Research, Vol. 12 Issue 2, pp28-49

Kranacher M. J., Riley R.A. and Wells, J. (2010, 2011), Forensic Accounting and Fraud Examination, Wiley, Hoboken, New Jersey

Morales, J., Gendron, Y., and Guenin-Paracini , H. (2014), "The construction of the risky individual and vigilant organization: a genealogy of the fraud triangle", Accounting, Organisations and Society, Vol 39, pp170-194

Riemer, S.H. (1941), “Embezzlement: Pathological Basis", Journal of Criminal Law and Criminology, Vol. 32 issue 4, pp411-423

Schuchter, A. and Levi, M. (2015), "Beyond the Fraud Triangle: Swiss and Austrian Elite Fraudsters, Accounting Forum, Vol 39, pp176-187

Sutherland, E. H. (1939), Principles of Criminology, JB Lippincott, Chicago

Sutherland, E. H. (1940), "White Collar Criminality”, American Sociological Review, Vol 5, February 1940, pp1-12

Sutherland, E.H. (1942) "The Development of the Theory of Differential Association", The Ohio Valley Sociologist, Vol 15 No1 (May 1942) p3

Wolfe, D. T. and Hermanson, D. R. (2004), "The Fraud Diamond: Considering four elements of fraud", The CPA Journal, Vol 74 (12) pp38-42 
Zeleny, L. (1933), "Feeblemindedness and criminal conduct", American Journal of Sociology, v38, pp564-576

Zietz, D. (1981). Women who embezzle or defraud: A study of convicted felons. New York, NY: Praeger 